\title{
EVALUATION OF THE IMPLANTATION IN PINEALECTOMIZED AND/OR SUBMITTED TO THE CONSTANT ILLUMINATION RATS
}

\author{
EVALUACIÓN DE LA IMPLANTACIÓN EN RATAS PINEALECTOMIZADAS \\ Y/O SOMETIDAS A CONSTANTE ILUMINACIÓN
}

\author{
"Álvaro Aguiar Coelho Teixeira; **Manuel de Jesus Simões; *Valéria Wanderley Teixeira \& **José Maria Soares Júnior
}

TEIXEIRA, A. A. C.; SIMÕES, M. J.; WANDERLEY-TEIXEIRA, V. \& SOARES JR. J. M. Evaluation of the implantation in pinealectomized and/or submitted to the constant illumination rats. Int. J. Morphol., 22(3):189-194, 2004.

SUMMARY: In this paper we evaluated the morphologic and quantitative aspects of the implantations sites in uteruses of female pinealectomized and/or submitted to the constant illumination rats. The experimental groups were: I - normal female rats maintained in a clear/dark cycle of 12/12 hours, for two months, mated and euthanasiated in the 6th day of pregnancy (control); II - female shampinealectomized rats maintained in a clear/dark cycle of 12/12 hours, for two months, mated and euthanasiated in the 6th day of pregnancy (control); III - female pinealectomized rats, maintained in a clear/dark cycle of 12/12 hours, for two months, mated and euthanasiated in the 6th day of pregnancy; IV - normal female rats maintained in constant illumination for two months, mated and euthanasiated in the 6th day of pregnancy; V - female sham-pinealectomized rats, maintained in constant illumination for two months, mated and euthanasiated in the 6th day of pregnancy; VI - female pinealectomized rats, maintained in constant illumination for two months, mated and euthanasiated in the 6th day of pregnancy. The means of the implantations sites showed that there were significant differences, where the groups III, IV, V and VI differed from the groups II and I, which presented the highest means. The groups III, IV, V and VI didn't differ amongst themselves. The sites in the control groups revealed the presence of small gaps containing blood, trophoblastic cells, and some polyploid cytotrophoblasts. In the groups III, IV, V and VI it was evidenced well-developed gaps at the sites, with trophoblasts, cytotrophoblasts with high polyploidy degree and syncytiotrophoblasts. In conclusion the pinealectomy and/or constant illumination reduce of the number implants in female rats besides to stimulate the development of the implantation sites, indicating thus a probable function of the melatonin in the viability of implantation of the blastocyst.

KEY WORDS: 1. Pinealectomy; 2. Constant illumination; 3. Implantation; 4. Blastocyst.

\section{INTRODUCTION}

The rhythm of secretion of the melatonin induces variations in the reproductive function of seasonal animals, where the natural production of this hormone is longer in the winter that in the summer (Reiter, 1991, 1993; Weaver et al., 1993; Aleandri et al., 1996).

In the rat (Rattus norvegicus), a non-seasonal reproducer, the melatonin peak, just like in humans, it is reached during the first half of the phase of darkness $( \pm$ around midnight), followed by a gradual reduction in the production of this hormone, in the second half of the night (Reiter, 1993). However, this species has the reproductive function influenced by the photoperiod, melatonin administration and for the pinealectomy (Aleandri et al.; Santos, 1996; Teixeira et al., 2002; Santos et al., 2003).
According to Matsumoto et al., (1991); Ayar et al., (2001) and Schlabritz-Loutsevitch et al., (2003) the target of melatonin in the uterus is the miometrium, where we found receivers for the MT1 and MT2 melatonin, through which they can modulatethe miometrial operation, inhibiting the spontaneous contractions induced by the oxytocin. However, Zhao et al., (2002) report the presence of the MT1receiver in the endometrial stroma, which decreases progressively during the decidualization, staying in this state, until the end of the gestation.

Several researches have demonstrated that the melatonin levels in the plasma increase during the gestation, reaching high values in the end of this period, suggesting that that hormone plays an important role in the maintenance

\footnotetext{
Department of Morphology and Animal Physiology, Universidade Federal Rural de Pernambuco, Recife - PE, Brasil.

**Histology of Discipline, Universidade Federal de São Paulo - EPM, São Paulo, Brasil.
} 
of the gestation (Kivelä, 1991; Sandyk et al., 1992; Bishnupuri \& Haldar, 2000, 2001; Nakamura et al., 2001). However, little it is known about the importance of the melatonin on the implantation process.

Thus, after what has been exposed, the present research had the objective of evaluating quantitatively and morphologically the influence of pinealectomy and/or constant illumination on the implantation in female rats.

\section{MATERIAL AND METHOD}

We used 60 albino female rats (Rattus norvegicus albinus) aged 90 days, virgins, weighing $200 \mathrm{~g}$ approximately, from the Wistar lineage, coming from the Biotério do Departmento de Morfologia Fisiologia Animal, da Universidade Federal Rural de Pernambuco, which were divided, at random, in six groups:

Group I - Normal female rats maintained in a clear/dark cycle of 12/12 hours, for two months, mated and euthanasiated in the 6th day of pregnancy (control group);

Group II - Female sham-pinealectomized rats maintained in a clear/dark cycle of 12/12 hours, for two months, mated and euthanasiated in the 6th day of pregnancy (control group);

Group III - Female pinealectomized rats, maintained in a clear/dark cycle of 12/12 hours, for two months, mated and euthanasiated in the 6th day of pregnancy;

Group IV - Normal female rats maintained in constant illumination for two months, mated and euthanasiated in the 6th day of pregnancy;

Group V - Female sham-pinealectomized rats, maintained in constant illumination for two months, mated and euthanasiated in the 6th day of pregnancy;

Group VI - Female pinealectomized rats, maintained in constant illumination for two months, mated and euthanasiated in the 6th day of pregnancy.

The pinealectomy was performed in animals anesthetized previously with sodic thiopental, in the dosage of $50 \mathrm{mg} / \mathrm{Kg}$, through intraperitonial way. After was proceeded to the pinealectomy technique described by Kuszak \& Rodin (1977). The luminous stimulate was obtained using a wooden box with area of $0.5 \mathrm{~m}^{3}$, with openings to allow the ventilation, containing two fluorescent lamps (PHILLIPS, 40W), which supplied appropriate and enough brightness, around 400 lux. After two months of experiment the females were mated in the proportion of a male for each three females, always in the beginning of the night. The following day colpocytologic exams were accomplished in the female rats, always in the period of the morning, for the confirmation of the mating, being taken as the parameter the presence of spermatozoids in the smears, being this day considered the first day of the pregnancy. In the sixth day after the mating it was proceeded the collection of the materials. For doing so, the animals were previously anesthetized with sodic thiopental, in the dosage of $50 \mathrm{mg} /$ $\mathrm{Kg}$, for intraperitoneal way, the uterine horns were taken out and fixed in the liquid of Boüin by 48 hours. Soon afterwards the animals were euthanasiated being deepened the anesthesia until the lethal dose. Later it was proceeded the counting of the implantation sites and the processing for inclusion in "paraplast" and coloration for the hematoxilin eosin (H.E). Comparative analyses of the means of the implantation sites were accomplished, through the Analysis of Variance for an entirely casualized delineation using the test of Tukey with $95 \%$ of significance.

\section{RESULTS}

According to the statistical analysis of the means of the implantation sites, there was a meaningful difference, where the groups III, IV, V and VI differed from the groups I and II, which presented the highest mean (Table I). We should mention, although, that the groups III, IV, V and VI didn't differ amongst themselves. The morphologic analysis of the implantation sites in the animals from groups I and II revealed the presence of small gaps containing blood, besides the trophoblast, which came in several stages development, where we found intermediate and giant trophoblastic cells (Fig. 1). We still noticed the presence of the cytotrophoblast: cells with relatively large nuclei, vesiculated, clear cytoplasm, with mitotic activity, being observed polyploidy in some of them (Fig. 2). The syncytiotrophoblast formation was not observed in these sites. In the groups II, III, IV, V and VI the implantation sites presented similar morphologic aspects amongst themselves, showing great gaps containing maternal blood, indicating thus an intense erosive activity of the trophoblast on the maternal vases. The observed cellular types were the trophoblast, which also come in different development stages, being more common the intermediate trophoblast, and the cytotrophoblast, with the same morphologic characteristics found in the control groups, however presenting larger mitotic activity and high polyploidy degree (Figs. 3 and 4). We noticed the syncytiotrophoblast presence in those sites (Fig. 5). 
Table I. Means of the implantation sites in the experimental groups.

\begin{tabular}{cc}
\hline Groups & ${ }^{1}$ Mean \pm Standard Deviation \\
G I & $11,60 \pm 1,30 \mathrm{a}$ \\
GII & $11,40 \pm 1,40 \mathrm{a}$ \\
GIII & $7,50 \pm 1,66 \mathrm{~b}$ \\
GIV & $6,50 \pm 1,58 \mathrm{~b}$ \\
GV & $6,40 \pm 1,71 \mathrm{~b}$ \\
GVI & $5,60 \pm 0,84 \mathrm{~b}$ \\
\hline C.V.(\%) & 18,01
\end{tabular}

${ }^{1}$ Means followed by the same letter don't differ statistically amongst themselves for the Test of Tukey $(\mathrm{P} \leq 0,05)$.

C.V. Coefficient of Variation.

\section{DISCUSSION}

Several authors mention that the critical point during the gestation in mammals is the implantation of the blastocyst, when this is arrested to the wall of the uterus, because the development of the periimplanted embryo is now dependent of the maternal environment, where the mechanism of the implantation is conditioned to a complex interaction among peptids, steroid hormones, endometrium and blastocyst (Stewart et al., 1992; Paria et al., 2000; Paria et al., 2001). Furthermore agreement of with Sandyk et al., a functional defi-

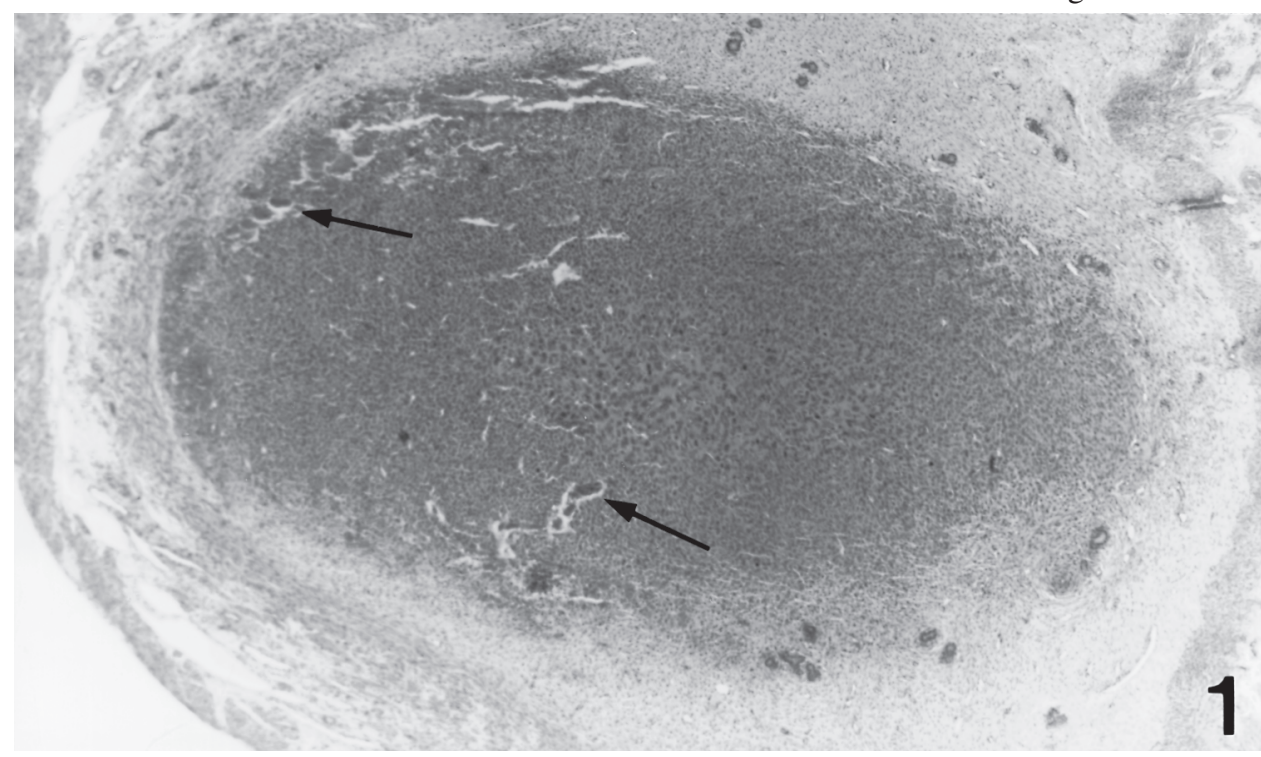

Fig. 1. Photomicrography of the implantation site in the female rat of the group I. Small gaps containing maternal blood (arrows). H. E. 42X.

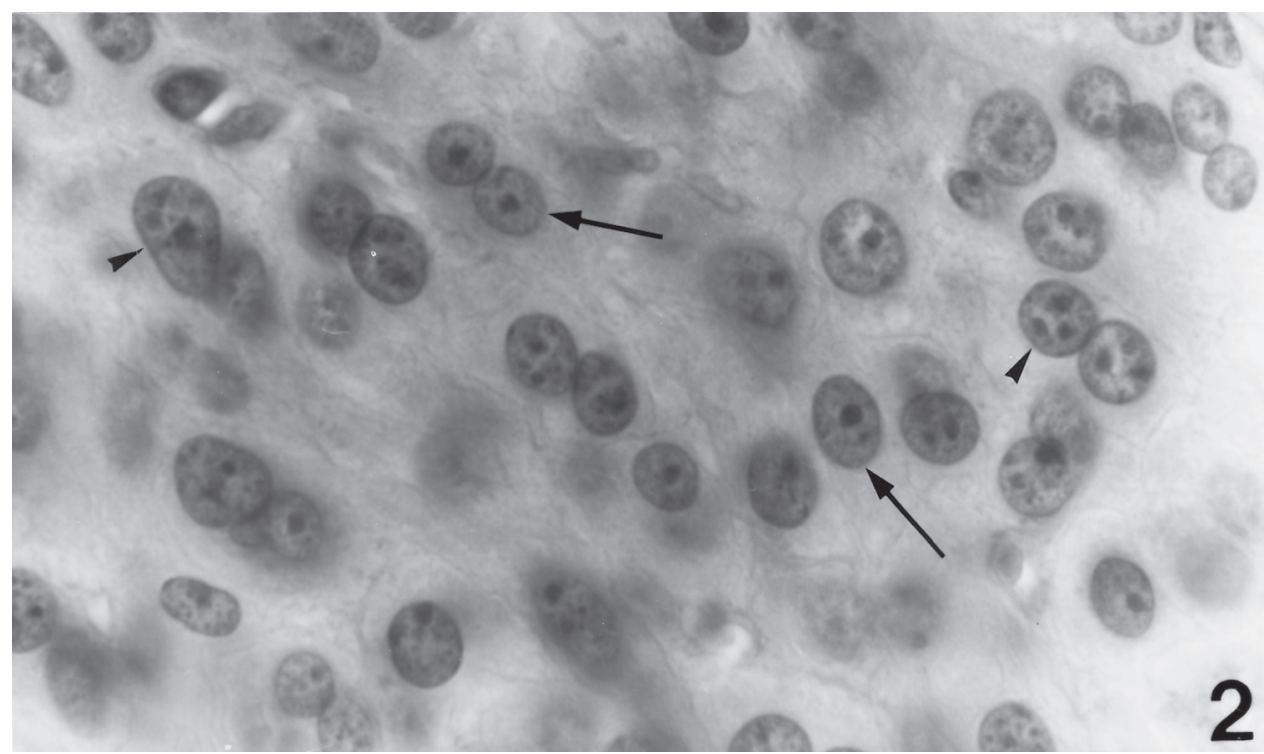

ciency in the melatonin production in the beginning of the gestation, can cause spontaneous abortions, in cases where chromosomic anomalies and structural abnormalities of the uterus were excluded.

In the animals of the groups III, IV, V and VI was demonstrating clearly an action of the pinealectomy and/or constant illumination factors on the interaction between the endometrium and the blastocyst. These fact can be possibly related to a decrease of the progesterone levels and consequently a reduction of the activity of the endometrial glands, because according to Sandyk et al., the melatonin stimulates the progesterone secretion that prevents the immunological rejection of the trophoblast. Besides, female rats when submitted to the pinealectomy or constant illumination present low melatonin levels in the sanguine current, consequently larger action of the estrogenic and androgenic hormones, producing morphologic and quantitative alterations in these glands (Santos, 1996; Dardes et al., 2000; Mendonça, et al., 2002; Teixeira et al., 2002).

Fig. 2. Photomicrography of the implantation site in the female rat of the group I. Trophoblast (arrows) and cytotrophoblast with large and vesiculated nuclei (arrow point). H. E. 1071X. 

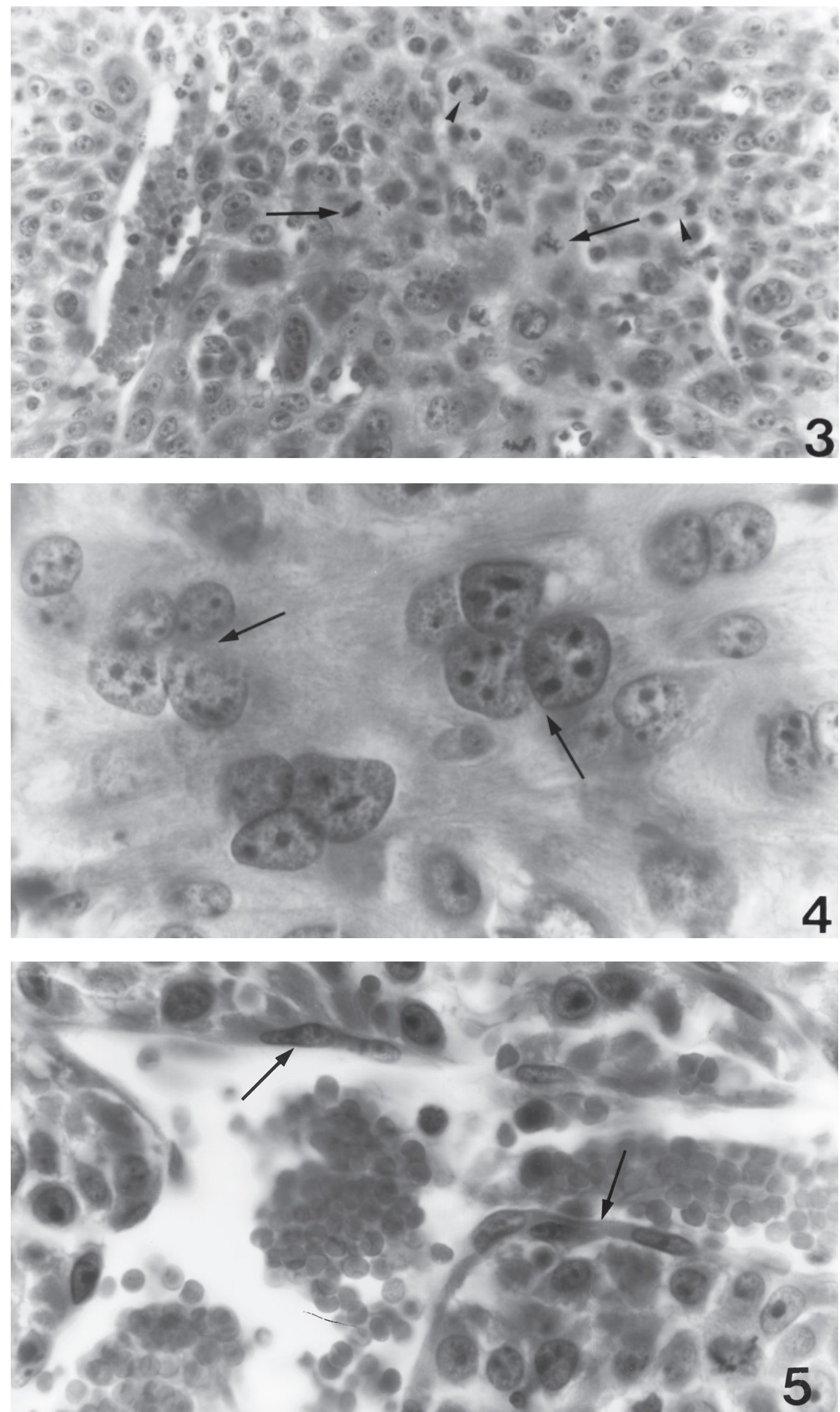

Fig. 3. Photomicrography of the implantation site in the female rat of the group III. Cytotrophoblast in mitosis: metaphase (arrows) and anaphase (arrow points). H.E. $428 \mathrm{X}$.

Fig. 4. Photomicrography of the implantation site in the female rat of the group IV. Cytotrophoblat with high polylpoidy degree (arrows). H.E. 1071X.

Fig. 5. Photomicrography of the implantation site in the female rat of the group VI. Syncytiotrophoblast presence delimiting the gaps (arrows). H. E. 1071X. 
The implantation sites in the animals pinealectomizead and/ or submitted to the constant illumination showed that these presented with great gaps containing blood maternal, larger mitotic activity of the cytotrophoblast and high polyploidy degree, besides the syncytiotrophoblast presence, demonstrating to be entering in a vilositary stage, indicating, therefore a larger evolution than the sites of the control groups, which came in lacunar stage.

This discovery can be related to the increase of the estrogen in these animals, as already mentioned previously. In fact, according to Cronier et al., (1999); Zybina et al., (2001); Natale et al., (2003) and Sutherland, (2003), the presence of the estrogen stimulates the morphologic and functional differentiation of the trophoblast during the gestation.

With relationship the presence of citotrophoblastic polyploid cells Zybina \& Zybina (2000), Zybina et al.,
(2000), and Zybina et al., (2001) the polyploidy in the cytotrophoblast is a common process during the formation of the placenta in rodents and carnivorous. Furthermore the observation of several polyploidy degrees is due to the different conditions of invasion of the citotrophoblast to the formation of the placenta (Zybina et al. 2001). So, the contact between the cytotrophoblast and the endometrial cells, in the course of the implantation, can result in damages in the genetic material of the cytotrophoblast. This way, the duplication of the genoma protects those cells of possible changes in their hereditary material (Zybina et al., 2001).

We concluded this way that the pinealectomy, the constant illumination or association of these factors they induce a reduction of the blastocysts number implanted in female rats besides to stimulate the development of the implantation sites, indicating that the melatonin can have an important function in the viability of implantation of the blastocyst, and in the process of formation of the placenta in these animals.

TEIXEIRA, A. A. C.; SIMÕES, M. J.; WANDERLEY-TEIXEIRA, V. \& SOARES JR. J. M. Evaluación de la implantación en ratas pinealectomizadas y/o sometidas a constante iluminación. Int. J. Morphol., 22(3):189-194, 2004.

RESUMEN: En este trabajo evaluamos los aspectos morfológicos y cuantitativos de los sitios de implantaciones en úteros de ratas pinealectomizadas y/o sometidas a iluminación constante. Los grupos experimentales fueron: I - ratas normales mantenidas en ciclo claro / oscuro de 12/12 horas, durante dos meses, cruzadas y sacrificadass en el 60 día de preñez (control); II - ratas sham-pinealectomizadas mantenidas en ciclo claro/oscuro de 12/12 horas, durante dos meses, cruzadas y sacrificadas en el 60 día de preñez (control); III - ratas pinealectomizadas mantenidas en ciclo claro/oscuro de 12/12 horas, durante dos meses, cruzadas y sacrificadas en el 60 día de preñez; IV - ratas normales mantenidas en constante iluminación durante dos meses acasaladas y sacrificadas en el 60 día de preñez; $\mathrm{V}$ - ratas sham-pinealectomiazadas mantenidas en constante iluminación durante dos meses, cruzadas y sacrificadas en el 60 día de preñez; VI - ratas pinealectomizadas, mantenidas en constante iluminación durante dos meses, cruzadas y sacrificadas en el 60 día de preñez. El análisis estadístico de las medias de los sitios de implantaciones mostró que hubo diferencia significativa, donde los grupos III, IV, V y VI diferían de los grupos I y II, los cuales presentaron las mayores medias. Los grupos III, IV, V y VI no son diferentes entre sí. El análisis morfológico de los sitios en los grupos controles reveló la presencia de pequeñas lagunas conteniendo sangre, además de células trofoblásticas y algunos citrofoblastos poliploides. En los grupos III, IV, V y VI se evidenció lagunas muy desarrolladas en los sitios, con trofoblastos, citrofoblastos con alto grado de poliploidia y sinciciotrofoblastos. Concluimos que la pinealectomía y/o constante iluminación llevan a una reducción del número de blastocistos implantados en ratas, además estimula el desarrollo de los sitios de implantación, indicando así; que la melatonina puede tener importante función en la viabilidad de implantación del blastocisto.

PALABRAS CLAVE: 1. Pinealectomía; 2. Iluminación constante; 3. Implantación. 4. Blastocisto.

\section{REFERENCES}

Aleandri, V.; Spina, V. \& Moroni, A. The pineal gland and reproduction. Hum. Reprod., 2(3):225-35, 1996.

Ayar, A.; Kutlu, S.; Yilmaz, B. \& Kelestimur, H. Melatonin inhibits spontaneous and oxytocin-induced contractions of rat myometrium in vitro. Neuroendocrinol. Lett., 22(3):199207, 2001.

Bishnupuri, K. S. \& Haldar, C. Profile of organ weights and plasma concentrations of melatonin, estradiol and progesterone during gestation and post-parturition periods in female indian palm squirrel Funambulus pennanti. Indian J. Exp. Biol., 38(10):974-81, 2000.

Bishnupuri, K. S. \& Haldar, C. Maternal transfer of melatonin alters tho growth and sexual maturation of young indian palm squirrel Funambulus pennanti. Biol. Signais Recent., 10(5):317-25, 2001.

Cronier, L.; Guibourdenche, J.; Niger, C. \& Malassine, A. Oestradiol stimulates morphological and functional differentiation of human villous cytotrophoblast. Placenta, 20(8):669-76, 1999. 
Dardes, R. C.; Baracat, E. C. \& Simões, M. J. Modulation of estrous cycle and LH, FSH and melatonin levels by pinealectomy and sham-pinealectomy in female rats. Prog Neuropsychopharmacol. Biol. Psychiatry, 24(3):441-53, 2000.

Kivelä, A. Serum melatonin during human pregnancy. Acta Endocrinol. (Copenh)., 124(3):233-7, 1991.

Kuszak, J.\& Rodin, M. A new technique of pinealectomy for adult rats. Experientia, 33: 283-4, 1977.

Matsumoto, T. Hess, D. L.; Kaushal, K. M.; Valenzuela, G. J. Yellon, S. M. \& Ducsay, C. A. - Circadian myometrial and endocrine rhytms in pregnant rhesus macaque: effects of Constant light and timed melatonin infusion. Am. J. Obstet. Gynecol., 165(6):1777-84, 1991.

Mendonça, F. S.; Evêncio-Neto, J.; Baratella-Evêncio, L. Teixeira, A. A. C.; Wanderley-Teixeira, V.; Mendonça, J. S.; Medeiros, J. P.; Melo, A. H. \& Soares, A. P. Avaliação do ciclo estral de ratas (Rattus norvegicus albinus) pinealectomizadas e submetidas a ausência de luz. Arq. Inst. Biol., 69(supl.):1057, 2002.

Nakamura, Y.; Tamura, H.; Kashida, S.; Takayama, H.; Yamagata, Y.; Karube, A.; Sugino, N. \& Kato, H. Changes of serum melatonin level and its relationship to feto-placental unit during pregnancy. J. Pineal Res., 30(1):29-33, 2001.

Natale, A.; Candiani, M.; Merlo, D.; Izzo, S.; Gruft, L. \& Busacca, M. Human chorionic gonadotropin level as a predictor of trophoblastic infiltration into the tubal wall in ectopic pregnancy: a blinded study. Fertility \& Sterility, 79(4):981-6, 2003.

Paria, B. C.; Lim, H. Das, S. K.; Reese, J. \& Dey, S. K. Molecular signaling in uterine receptivity for implantation. Cell \& Developmental Biology, 11:67-76, 2000.

Paria, B. C.; Song, H. \& Dey, S. K. Implantation: molecular basis of embryo-uterine dialogue. Int. J. Dev. Biol., 45(3):597- 605, 2001.

Reiter, R. J. Pineal melatonin: cell biology of its synthesis and of its physiological interactions. Endocr. Soc., 2:151-80, 1991.

Reiter, R. J. The melatonin rhythm: both a clock and a calendar. Experientia,, 49(9):654-64, 1993.

Sandyk, R.; Anastasiadis, P. G.; Anninos, P. A. \& Tsagas, N. The pineal gland and spontaneous abortions implications for therapy with melatonin and magnetic field. Int. J. Neurosci., 62(3-4):243-50, 1992.

Santos, J. M. Aspectos morfológicos do endométrio de ratas em estro permanente ou ooforectomizadas, tratadas com estrogênio elou dexametasona. São Paulo, 1996. [Tese de Mestrado - Escola Paulista de Medicina].

Santos, K. R. P.; Mendonça, J. S.; Wanderley-Teixeira, V. \& Teixeira, A. A. C. Influência da ausência de luz sobre o ciclo estral de ratas. Arq. Inst. Biol., 70(1):23-7, 2003.
Schlabritz-Loutsevitch, N.; Hellner, N.; Middendorf, R.; Müller, D. \& Olcese, J. The human myometrium as a target melatonin. J. Clin. Endocrinol. Metab., 88(2):908-13, 2003.

Stewart, C. L.; Kaspar, P.; Brunet, L. J.; Ehatt, H.; Gadi, I.; Konigen, F. \& Abbondanzo, S. J. Blastocyst implantation depends on maternal expression of leukemia inhibitory factor. Nature, 359:76-9, 1992.

Sutherland, A. Mechanisms of implantation in the mouse: differentiation and functional importance of trophoblast giant cell behavior. Developmental Biology, 258:241-51, 2003.

Teixeira, A. A. C.; Simões, M. J.; Evêncio Neto, J. \& WanderleyTeixeira, V. Morphologic aspects of the endometrium, in the estrus phase, of pinealectomized rats. Rev. Chil. Anat., 20(2): 145-9, 2002.

Weaver, D. R.; Stehle, J. H.; Stopa, E. G. \& Reppert, S.M. Melatonin receptors in human hypothalamus and pituitary: implications for circadian and reprodutive responses to melatonin. Clin. Endocrinol. Metab., 76:295-301, 1993.

Zhao, H.; Pang, S. F. \& Poon, A. M. - Variations of mt1 melatonin receptor density in the rat uterus during decidualization, the estrous cycle and in response to exogenous steriod treatment. J. Pineal Res., 33(3):140-5, 2002.

Zybina, E. V. \& Zybina, T. G. - Genome multiplication in the tertiary giant trophoblast cells in the course of their endovascular and interstitial invasion into rat placenta decidua basalis. Early Pregman Biol. Medicine, 4: 99-109, 2000.

Zybina, T. G.; Zybina, E. V. \& Stein G. I. Trophoblast cell invasiveness and capability for the cell and genome reproduction in rat placenta. Earl Pregman Biol. Medicine, 4: 39-57, 2000.

Zybina, T. G.; Zybina, E. V.; Kiknadze, I. I. \& Zhelezova, A. I. Polyploidization in the trophoblast and uterine glandular epithelium of the endotheliochorial placenta of silver fox (Vulpes fulvus Desm.), as revealed by the DNA content. Placenta, 22:490-8, 2001.

Correspondence to:

Prof. Álvaro Aguiar Coelho Teixeira

Universidade Federal de Pernambuco

Departamento de Morfologia e Fisiologia Animal

Área de Histologia

Rua Dom Manoel de Medeiros, $S / \mathcal{N}$

CEP 52.171-900

Dos Irmãos - Recife - PE

BRASIL

Email : aact@6ol.com.6r

Receiced : 11-04-2004

Accepted : 23-06-2004 